\title{
Analisis Digital Citra Satelit Worldview-2 untuk Ekstraksi Kedalaman Perairan Laut di Sebagian Perairan Pulau Parang, Kepulauan Karimunjawa, Provinsi Jawa Tengah
}

\author{
Surya N. Syaiful ${ }^{1}$, Muhammad Helmi ${ }^{1,2}$ dan Sugeng Widada ${ }^{1}$, Rikha Widiaratih ${ }^{1}$, Petrus Subhardjo ${ }^{1}$, \\ Agus Anugroho Dwi Suryoputro' \\ ${ }^{1}$ Oceanography Department, Faculty of Fisheries and Marine Science, Universitas Diponegoro \\ Jl. Prof. Sudarto, SH., Tembalang, Semarang, Central Java (50275) Indonesia \\ ${ }^{2}$ Center of Excellent for Science and Technology (PUI), Center for Coastal Disaster Mitigation and Rehabilitation \\ Studies (CoREM), Universitas Diponegoro, Indonesia \\ Email corresponding author: suryanugraha.syaiful@gmail.com
}

\begin{abstract}
Abstrak
Teknologi penginderaan jauh (remote sensing) memungkinkan untuk dilakukannya pemetaan batimetri perairan pada daerah yang memiliki tingkat perubahan kedalaman secara cepat dan juga dangkal sekalipun dengan menggunakan citra satelit. Tujuan dari penelitian ini yaitu untuk mengetetahui pasangan band rasio terbaik dari citra satelit Worldview-2 untuk membuat peta batimetri pada perairan serta mengetahui informasi kedalaman di Pulau Parang, Kepulauan Karimunjawa. Penelitian ini menggunakan citra satelit Worldview-2 sebagian Pulau Parang, Kepulauan Karimunjawa dengan empat saluran multispektral, yaitu band biru pesisir, biru, hijau dan kuning, yang dikombinasikan menjadi 8 band rasio dan diintegrasikan dengan data kedalaman hasil pengukuran lapangan sebanyak 300 titik sampel untuk uji akurasi dan 150 titik sampel untuk pemodelan batimetri pada rentang kedalaman 0-20 m. Hasil pemodelan menunjukkan bahwa model empiris batimetri terbaik adalah rasio band biru dan band hijau dengan nilai $\mathrm{R}^{2}$ sebesar 0,6976 dan nilai RMSE sebesar 4,00. Penelitian ini menunujukan bahwa band rasio biru / hijau dapat menampilakn kedalaman laut di Pulau Parang, Kepulauan Karimunjawa dari 0 m higgga $17 \mathrm{~m}$.
\end{abstract}

Kata kunci : Pemetaan, Batimetri, Band Rasio, Worldview-2, dan Karimunjawa

\begin{abstract}
Remote sensing technology makes it possible to build bathymetry mapping of waters where has depth various and shallow even using satellite imagery. This research has purpose to find out the best band ratio pair from Worldview-2 satellite imagery to make a aquatic bathymetry map, also find out the information about various of depth in Parang Island, Karimunjawa Islands. This research using Worldview-2 satellite imagery in several part of Parang Island, Karimunjawa Islands with 4 (four) multispectral channels; (1)Blue-Coast Band, (2)Blue, (3)Green, and (4)Yellow, which are combined into 8 (eight) ratio band and integrated with depth data from field measurement. There is 300 sample point for accuracy test and 150 sample point for bathymetry modelling in depth range 0-20 $\mathrm{m}$. The modelling result shows that best empirical bathymetry model is the ratio of blue band and green band with the value of $R^{2}$ is 0,6976 and the RMSE value is 4,00. This research suggests that the ratio of blue / green bands can show the depth of the sea on Parang Island, Karimunjawa Islands from $0 \mathrm{~m}$ to $17 \mathrm{~m}$.
\end{abstract}

Keywords: Mapping, Bathymery, Ratio Band, Worldview-2 Satellite Imagery, and Karimunjawa

\section{PENDAHULUAN}

Seiring dengan berkembangnya teknologi penginderaan jauh (remote sensing) memungkinkan untuk dilakukannya pemetaan batimetri perairan ataupun daerah yang memiliki tingkat perubahan kedalaman secara cepat ataupun daerah yang sangat dangkal sekalipun dengan menggunakan citra satelit (Nurkhayati dan Khakhim, 2013). Selain itu pemetaan dengan penginderaan jauh ini mampu menghemat biaya serta efektif dan 
efisien dalam pemetaan batimetri serta mampu mengkaji satu cakupan daerah yang luas dan mampu mendeteksi daerah yang sulit dijangkau sekalipun.

Pemetaan batimetri dengan menggunakan citra satelit bukan merupakan suatu hal yang baru lagi di dunia kelautan, namun masih belum banyak digunakan dalam memetakan batimetri di suatu perairan. Selain itu, pemetaan batimetri tidak hanya dipengaruhi oleh metode pendugaan namun juga dipengaruhi oleh citra wahana satelit yang dipakai, karena setiap wahana tersebut memiliki kedetailan yang berbeda-beda baik dari resolusi piksel maupun kekuatan sensor dalam pendeteksian. Adapun citra satelit yang telah digunakan dalam pendugaan batimetri yaitu satelit SPOT, Formosat, Landsat, Ikonos, Quickbird dan yang terbaru yaitu Worldview-2.

Penggunaan metode Stumpf, et al. (2003), masih jarang digunakan oleh para peneliti di Indonesia. Penelitian sebelumnya dengan menggunakan citra satelit Worldview-2 dilakukan oleh Subarno, et al. (2015), dengan perbandingan rasio terbaik yaitu coastal blue dan Green dengan $\mathrm{R}^{2}$ sebesar 0.673 . Selain itu Wicaksono dan Rahman (2019), memperoleh band hijau dan biru sebagai band rasio terbaik dengan $\mathrm{R}^{2}$ sebesar 0.632 . Hal tersebut adalah yang melatarbelakangi penggunaan metode Stumpf pada penelitian ini. Stumpf, et al. (2003), mengembangkan sebuah model rasio yang membandingkan 2 buah band (kanal) yang merupakan faktor reflektansi air. Stumpf beramsumsi dengan menggunakan perbandingan 2 kanal akan mengurangi efek albedo perairan yang selama ini menjadi masalah dalam pemetaan batimetri ataupun habitat perairan. Penelitian ini dilakukan di perairan Pulau Parang, Kepulauan Karimunjawa (Wicaksono dan Rahman, 2019). Tujuan dari penelitian ini yaitu untuk mendapatkan pasangan band rasio terbaik dalam membuat peta batimetri dan juga informasi kedalaman laut dari citra satelit Worldview-2 pada perairan Pulau Parang, Kepulauan Karimunjawa.

\section{MATERI DAN METODE}

Data utama yang digunakan pada penelitian ini yaitu data citra satelit Worldview-2 Pulau Parang perekaman tanggal 29 Oktober 2016 pukul 03.22 WIB dan data pengukuran kedalaman laut. Adapun data pendukung yang digunakan pada penelitian ini yaitu Peta Rupabumi Indonesia (RBI) Pulau Parang, Karimunjawa Skala 1 : 25.000 Publikasi BIG tahun 2017 dan data pasang surut Pulau Parang, Karimunjawa Publikasi BIG bulan November 2018. Data sekunder pasang surut selama 29 hari ini diolah dengan menggunakan metode admiraly untuk memperoleh komponen pasang surut. Data tersebut digunakan untuk dapat mengkoreksi nilai kedalaman yang terukur berdasarkan Lowest Low Water Level (LLWL) dan pada saat citra melakukan akuisisi data.

Peta lokasi penelitian pada wilayah perairan Pulau Parang, Kepulauan Karimunjawa dapat dilihat pada gambar berikut:

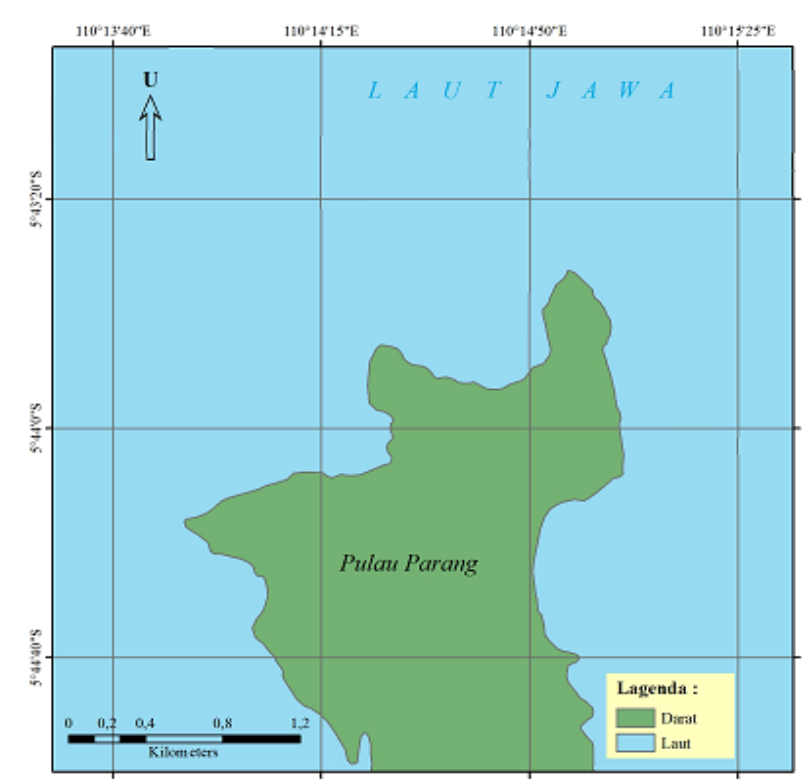

Gambar 1. Lokasi Penelitian pada Perairan Pulau Parang, Kepulauan Karimunjawa 
Pengambilan data lapangan meliputi data pengukuran kedalaman yang diperoleh dengan melakukan pemeruman menggunakan Echosounder Garmin GPS Map 585. Data pemeruman yang diperoleh merupakan susunan nilai elevasi data titik koordinat baik lintang (Y), bujur (X) dan data kedalaman (Z). Pemeruman dilakukan menggunakan metode random sampling. Metode random sampling adalah pengambilan sampel dari populiasi secara acak berdasarkan frekuensi probabilitas semua anggota populasi. Metode ini dipilih karena diharapkan dapat mewakili beberapa sampel dengan kedalaman yang berbeda - beda.

Pengolahan data lapangan menggunakan microsoft excel dimana data tersebut dikoreksi terlebih dahulu dengan pasang-surut. Hasil data lapangan tesebut dijadikan acuan dalam membangun model estimasi kedalaman dan uji akurasi terhadap hasil pengolahan citra. Dalam hal ini digunakan 150 sampel data sebagai pembangun model. Sedangkan untuk uji akurasi data digunakan 300 sampel data dengan variasi kedalaman yang sama yaitu 0 - $20 \mathrm{~m}$ namun dengan titik yang berbeda. Adapun peta lokasi survei untuk membangun model spasial kedalaman dan uji akurasi data dapat dilihat pada gambar dibawah ini.

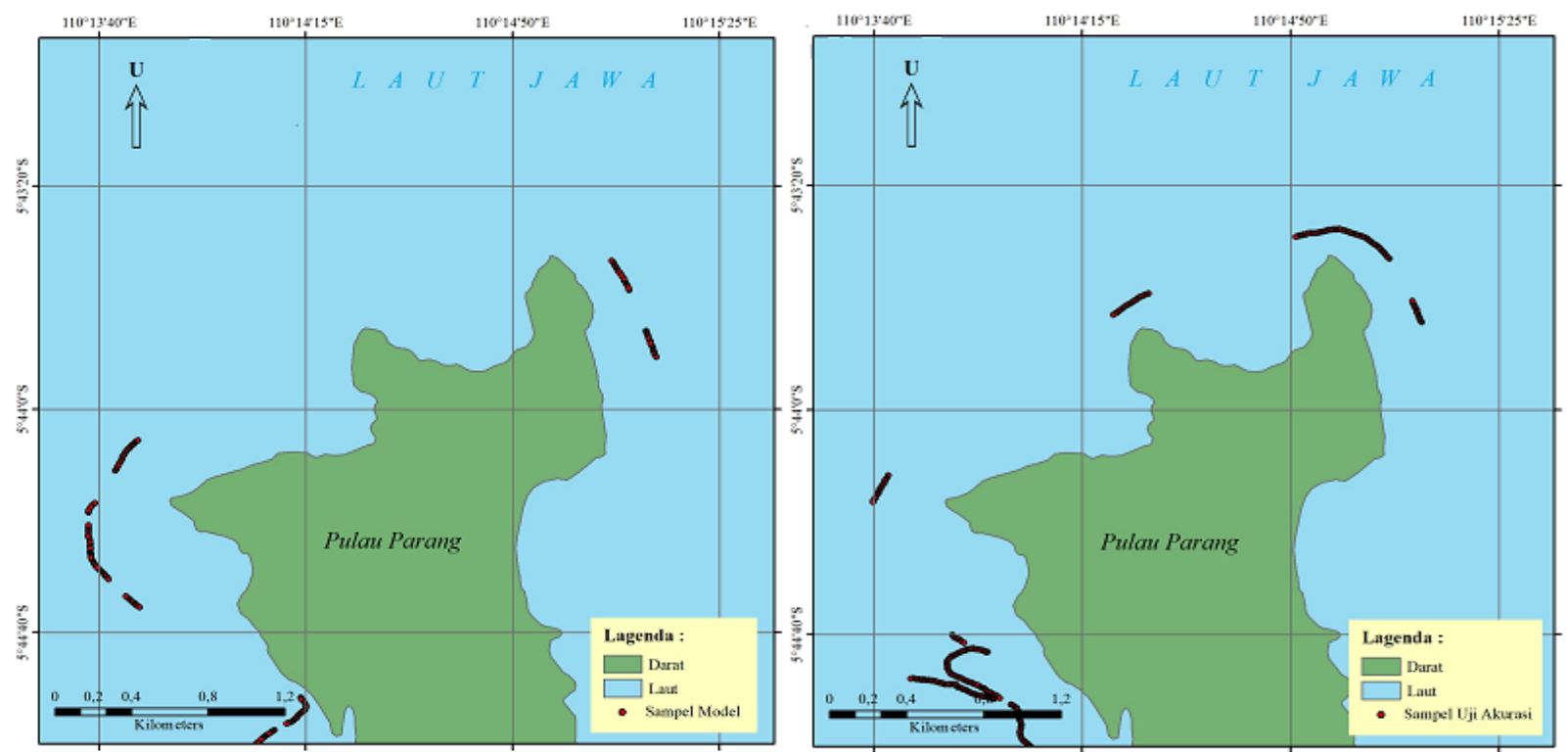

Gambar 2. Peta Lokasi Survei Pemeruman untuk Pengembangan (kiri) dan untuk Uji Akurasi Model (kanan) Model Spasial Kedalaman

Data hasil pemeruman batimetri di lokasi penelitian tidak dapat langsung digunakan. Data-data tersebut harus dikoreksi dahulu dengan menggunakan data pasang surut pada waktu melakukan survei batimetri dan pada saat citra satelit Worldview-2 merekam data. Data kedalaman hasil pemeruman True Water Level time (TWLt) dikoreksi menggunakan nilai Lowest Low Water Level (LLWL) dan nilai True Water Level time pada saat citra merekam (TWLt Citra) sebagai koreksi perubahan elevasi muka air berdasarkan LLWL dan pada saat citra melakukan perekaman. Dengan demikian akan didapatkan data kedalaman berdasarkan LLWL dan TWLt Citra.

Adapun citra satelit Worldview-2 yang digunakan pada penelitian ini telah terkoreksi geometri. Sehingga selanjutnya dilakukan koreksi atmosferik dan koreksi sunglint. Koreksi atmosferik dilakukan dengan melakukan kalibrasi radiometri yaitu mengkonversi nilai piksel Worldview-2 ke nilai at sensor reflectance dan kemudian melakukan koreksi atmosfer untuk menghilangkan path radiance dengan metode Dark Subtract (Wicaksono, 2015).

Citra Worldview-2 yang telah dikoreksi geometri dan radiometri selanjutnya dilakukan proses pemotongan citra (cropping) yang bertujuan menyesuaikan lokasi citra dengan wilayah penelitian. Setelah itu dilakukan koreksi sunglint ataupun penghilangan gangguan efek sunglint untuk menghilangkan gangguan gelombang perairan. Algoritma penghilangan efek sunglint dikembangkan Hochberg et al (2003), yang disempurnakan oleh Hedley, et al., (2005) seperti pada Persamaan 1. 
R'i = Ri - bi (Rnir - Minnir)

dimana :

$\mathrm{R}^{\prime} \mathrm{i}=$ Nilai kanal i setelah direduksi

$\mathrm{Ri}=$ Nilai kanal i awal

bi = Besarnya kemiringan regresi

Rnir = Nilai kanal

NIR Minnir = Nilai minimal kanal NIR

Citra WorldView-2 yang digunakan pada penelitian ini sebelum dilakukan proses lebih lanjut terlebih dahulu dilakukan masking untuk menutup wilayah daratan. Masking dilakukan dengan memanfaatkan band 8 (NIR-2), pemilihan band ini dikarenakan respon spektral antara darat dan laut pada band NIR-2 sangat kontras sehingga cukup baik digunakan untuk membedakan antara darat dan laut (Digital Globe, 2009).

Selanjutnya dilakukan estimasi kedalaman perairan pada citra satelit Worldview-2 dengan perbandingan kanal menurut Stumpf (2003). Perbandingan kanal yang digunakan dalam penelitian ini coastal/blue, coastal/green, coastal/yellow, blue/coastal, blue/green, bluelyellow, green/blue dan green/yellow. Stumpf membuat suatu formula penduga kedalaman dengan dua reflektansi panjang gelombang sebagai berikut :

$\mathrm{Z}=m_{1}\left(\frac{\ln \left(n R_{w}\left(\lambda_{i}\right)\right)}{\ln \left(n R_{w}\left(\lambda_{j}\right)\right)}\right)-m_{0}$

dimana :

$\mathrm{Z} \quad=$ Kedalaman

$m_{1} \quad=$ Koefisien kalibrasi

$R_{w}\left(\lambda_{i j}\right)=$ Reflektansi perpanjang gelombang yang

meninggalkan air

ln $\quad=$ Konstanta untuk menjaga rasio tetap positif

$m_{0} \quad=$ Koreksi kedalaman nol (0)

Dengan demikian untuk memperoleh kedalaman duga dari hasil regresi rasio nilai-nilai reflektansi pada masing-masing band yang digunakan, persamaan (2) dapat ditulis ulang berdasarkan persamaan regresi linear menjadi :

$\mathrm{Y}=\mathrm{aX}+\mathrm{b}$

dimana nilai slope (a) mewakili koefisien $\mathrm{m} 1$, nilai intercept (b) mewakili koefisien m0, dan nilai $\mathrm{X}$ mewakili hasil rasio nilai reflektansi pada band yang digunakan.

Untuk menentukan hubungan antara keduanya dilakukan dengan menggunakan koefisien korelasi. Dimana variabel $\mathrm{X}$, yaitu variabel data kedalaman hasil pengukuran lapangan dan $\mathrm{Y}$, yaitu data nilai kedalaman dari pengolahan citra. Kuat tidaknya hubungan antara keduanya ditunjukkan dengan tinggi tidaknya korelasi antara kedua variabel tersebut (Nurkhayati dan Khakhim, 2013). Rumus dasar koefisien korelasi ini adalah sebagai berikut :

$\mathrm{R}=\frac{n \sum \mathrm{xy}-\left(\sum \mathrm{x}\right)\left(\sum \mathrm{y}\right)}{\left(\mathrm{n} \sum \mathrm{x}^{2}-\left(\sum \mathrm{x}\right)^{2}\right)-\left(\mathrm{n} \sum y^{2}-\left(\sum y\right)^{2}\right)}$

Keterangan :

$\mathrm{n}=$ Jumlah sampel

$\mathrm{R}=$ Koefisien korelasi

$\mathrm{x}=$ Variabel yang mewakili nilai band rasio citra

$\mathrm{y}=$ Variabel yang mewakili nilai hasil pengukuran di lapangan 
Metode yang digunakan untuk menentukan akurasi dari peta batimetri yang dihasilkan yaitu RMSE. RMSE (root mean square error) merupakan akar dari rata - rata jumlah kuadrat nisbah antara selisih nilai kedalaman aktual hasil pengukuran lapangan dengan nilai kedalaman hasil estimasi pengolahan citra penginderaan jauh. RMSE dapat dihitung sebagai berikut :

$\mathrm{RMSE}=\sqrt{\frac{\sum_{\mathrm{t}=1}^{\mathrm{n}}(A t-F t)^{2}}{n}}$

Keterangan :

$A t=$ Nilai hasil estimasi kedalaman dari citra

$F t=$ Nilai hasil pengukuran lapangan

$n=$ Jumlah titik kedalaman yang digunakan dalam validitas model

\section{HASIL DAN PEMBAHASAN}

Hasil pengukuran pasang surut di lokasi penelitian diperoleh dari data pasut publikasi BIG stasiun Karimunjawa selama 29 hari yaitu pada tanggal 1 November 2018 sampai dengan tanggal 29 November 2018 yang dilanjutkan untuk analisa dengan metode Admiralty. Pengolahan pasang surut menggunakan metode Admiralty bertujuan untuk mendapatkan komponen pasang surut yang dilanjutkan dengan melakukan perhitungan untuk memperoleh nilai MSL (Mean Sea Level), LLWL (Lowest Low Water Level) dan HHWL (Highest High Water Level). Nilai - nilai komponen pasut ini dan juga nilai pasut pada saat perekaman citra akan digunakan sebagai data untuk melakukan koreksi dengan data hasil pengukuran batimetri.

Tabel 1. Nilai Elevasi Pasang Surut

\begin{tabular}{cc}
\hline Keterangan & Elevasi $(\mathrm{cm})$ \\
\hline MSL & 169 \\
\hline LLWL & 105 \\
\hline HHWL & 233 \\
\hline
\end{tabular}

HHWL $=234 \mathrm{~cm}$

MSL $=169 \mathrm{~cm}$

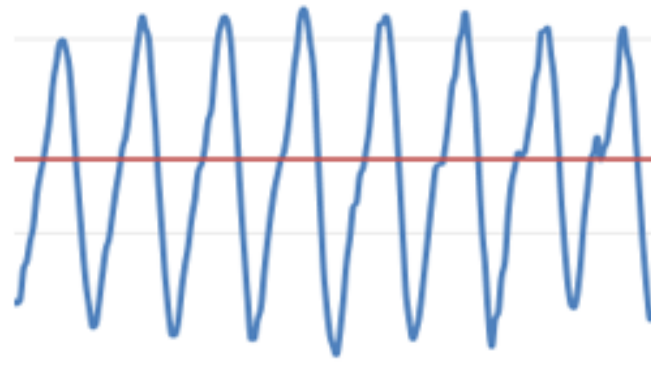

TWLt citra $=149 \mathrm{~cm}$

Nilai koreksi $=45 \mathrm{~cm}$

$L L W L=104 \mathrm{~cm}$

LLWL

Gambar 3. Koreksi Pasut Untuk Data Batimetri Pada Saat Perekaman Citra dan Berdasarkan Nilai LLWL

Hasil dari grafik regresi kombinasi 4 band dengan total masing - masing 8 band rasio pada saat kondisi pasut perekaman citra dan berdasarkan nilai LLWL. Grafik regresi ini berdasarkan nilai band rasio terhadap nilai kedalaman hasil pemeruman yang digunakan untuk membangun model batimetri diperoleh hasil yang berbeda-beda. Kombinasi band terbaik tesebut yaitu Band 2 / Band 3 dengan nilai koefisien korelasi (r) yaitu 0.8352 dan koefisien determinasi (R2) yaitu 0.6976 . 


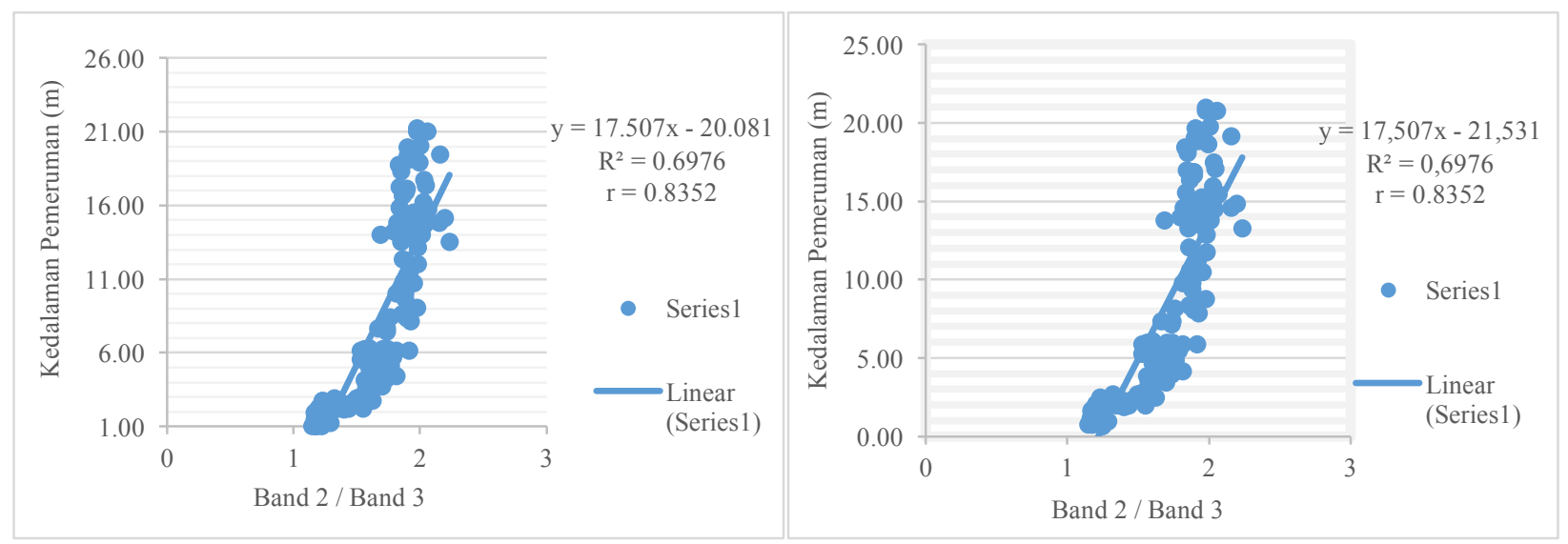

Gambar 4. Grafik Regresi Band 2 / Band 3 terhadap Kedalaman Pada Saat Kondisi Pasut Perekaman Citra (kiri) dan berdasarkan LLWL (kanan)

Tabel 2. Nilai Koefisien Korelasi dan Koefisien Determinasi Pada Saat Kondisi Pasut

\begin{tabular}{ccccc}
\hline \multicolumn{2}{c}{ Persamaan Linear } & \multirow{2}{*}{ Band Rasio } & \multirow{2}{*}{$\mathbf{R}^{2}$} & $\mathbf{r}$ \\
\hline \multicolumn{1}{c}{ Perekaman Citra } & LLWL & & & \\
\hline $\mathrm{y}=24.5 \mathrm{x}-29.64$ & $\mathrm{y}=24,5 \mathrm{x}-30,09$ & $\mathrm{~B} 1 / \mathrm{B} 2$ & 0.3033 & 0.5480 \\
\hline $\mathrm{y}=7.6464 \mathrm{x}-11.784$ & $\mathrm{y}=7,6464 \mathrm{x}-12,234$ & $\mathrm{~B} 1 / \mathrm{B} 3$ & 0.6131 & 0.7830 \\
\hline $\mathrm{y}=5.61 \mathrm{x}-11.675$ & $\mathrm{y}=5,61 \mathrm{x}-12,125$ & $\mathrm{~B} 1 / \mathrm{B} 4$ & 0.5304 & 0.7283 \\
\hline $\mathrm{y}=-53.394 \mathrm{x}+43.06$ & $\mathrm{y}=-53,394 \mathrm{x}+42,61$ & $\mathrm{~B} 2 / \mathrm{B} 1$ & 0.3004 & 0.5481 \\
\hline $\mathrm{y}=17.507 \mathrm{x}-20.081$ & $\mathrm{y}=17,507 \mathrm{x}-21,531$ & $\mathrm{~B} 2 / \mathrm{B} 3$ & 0.6976 & 0.8352 \\
\hline $\mathrm{y}=9.6558 \mathrm{x}-13.824$ & $\mathrm{y}=9,6558 \mathrm{x}-14,274$ & $\mathrm{~B} 2 / \mathrm{B} 4$ & 0.4369 & 0.6610 \\
\hline $\mathrm{y}=-40.052 \mathrm{x}+32.966$ & $\mathrm{y}=-40,052 \mathrm{x}+32,516$ & $\mathrm{~B} 3 / \mathrm{B} 2$ & 0.6248 & 0.7904 \\
\hline $\mathrm{y}=-5.8718 \mathrm{x}+16.19$ & $\mathrm{y}=-5,8718 \mathrm{x}+15,74$ & $\mathrm{~B} 3 / \mathrm{B} 4$ & 0.0295 & 0.1718
\end{tabular}

Dari pemodelan kedalaman berdasarkan persamaan linear regresi band rasio terbaik ini dilakukan uji akurasi data pengukuran lapangan dan data hasil pemodelan dengan menggunakan metode RMSE sehingga diperoleh hasil seperti pada tabel dibawah ini.

Tabel 3. Nilai RMSE Fungsi Kedalaman

\begin{tabular}{cc}
\hline Band Rasio & RMSE \\
\hline B1 / B3 & 4.41 \\
\hline B2 / B3 & 4.00 \\
\hline B3 / B2 & 4.37
\end{tabular}

Setelah dilakukan uji akurasi antara data lapangan dan data hasil pemodelan maka diperoleh nilai RMSE terendah yaitu pada band rasio band 2 / band 3. Sehingga persamaan linear yang digunakan dalam membuat peta batimetri yaitu berdasarkan band biru / hijau dengan nilai koefisien korelasi (r) yaitu 0.8352 dan koefisien determinasi $\left(R^{2}\right)$ sebesar 0.6976. Fungsi regresinya pada saat perekaman citra yaitu $(y=$ $17.507 *(\mathrm{Biru} / \mathrm{Hijau})-21.081)$. Sedangkan pada berdasarkan nilai LLWL yaitu $(\mathrm{y}=17.507 *(\mathrm{Biru} / \mathrm{Hijau})-$ 21.531). 


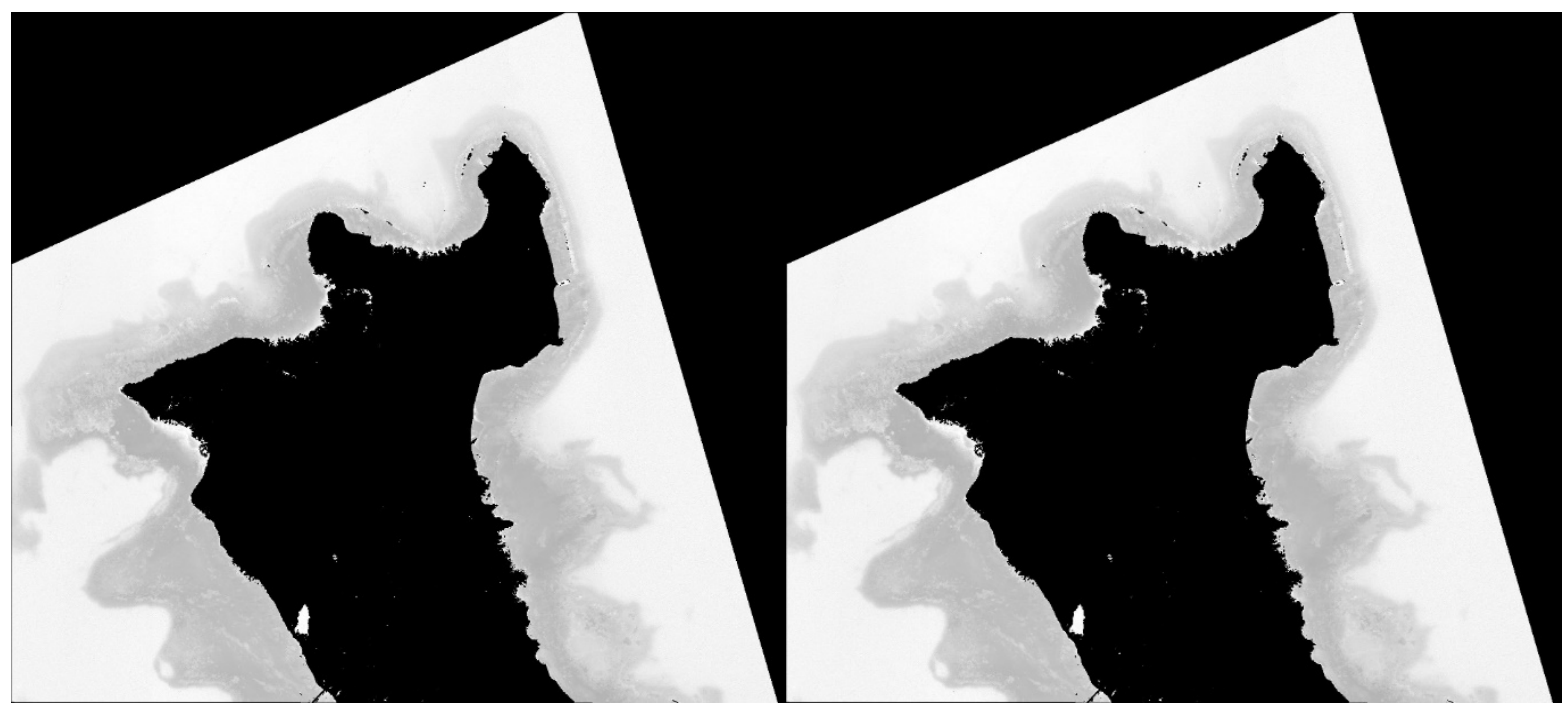

Gambar 5. Hasil Pengolahan Citra Band 2 / Band 3 Pada Saat Kondisi Pasut Perekaman Citra (kiri) dan berdasarkan LLWL (kanan)

Varian warna ini merupakan output default dari software envi sendiri dalam memodelkan kedalamanan. Dari hasil yang yang diperoleh tidak terlihat perbedaan yang cukup signifikan hal ini dikarenakan selisih antara kondisi pasut pada saat perekaman citra dan berdasarkan LLWL hanya berjarak 45 $\mathrm{cm}$. Hasil uji akurasi menunjukkan bahwa akurasi pemodelan batimetri menggunakan band rasio biru / hijau mempunyai nilai RMSE sebesar 4.00. Hasil ini menunjukan nilai RMSE pada penelitian lebih tinggi dibandingkan dengan penelitian yang dilakukan Nurkhayati dan Khakhim (2013), yang memperoleh nilai RMSE sebesar 2.31. Hal ini bisa disebabkan karena adanya bias dari citra, perbedaan tipe dan kualitas perairan serta rendahnya korelasi antara nilai band rasio terhadap nilai kedalaman.
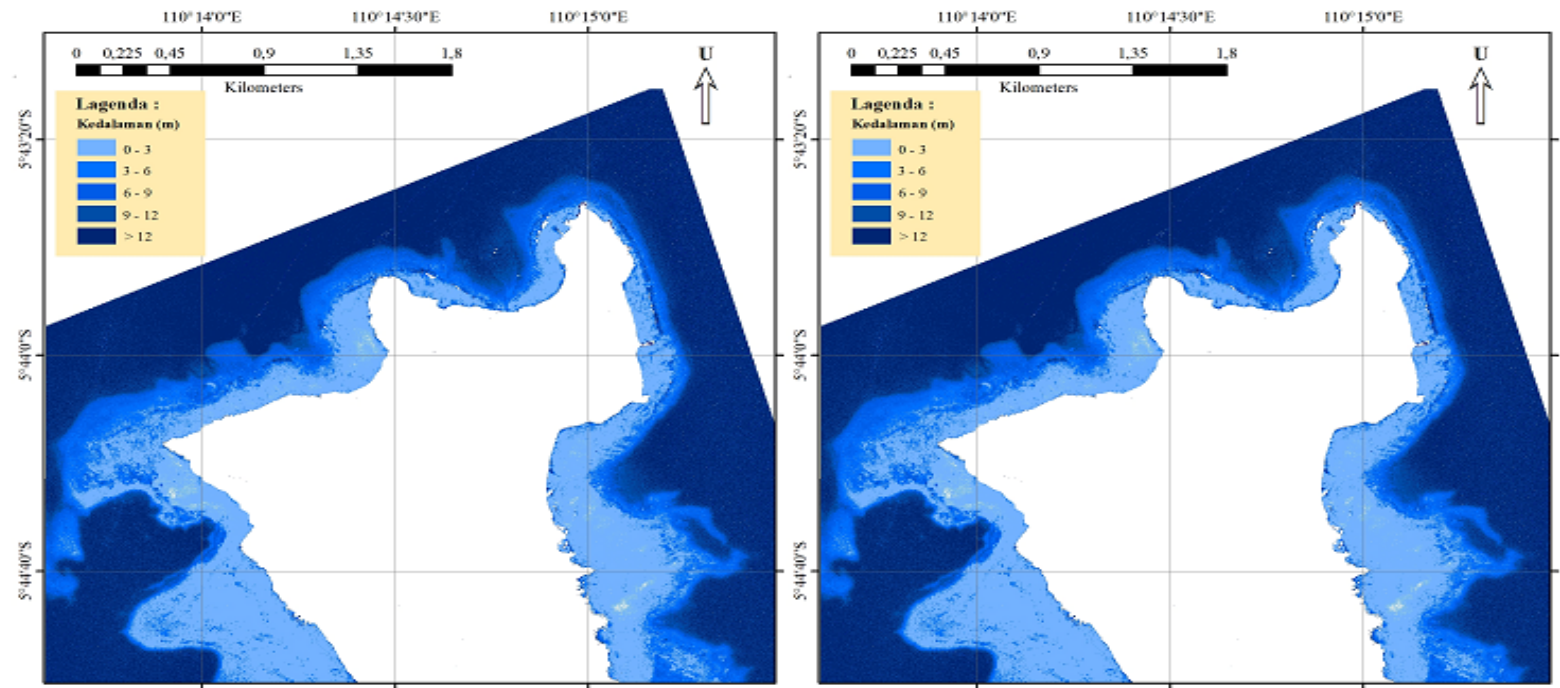

Gambar 6. Peta Batimetri Hasil Pemodelan Band 2 / Band 3 Pada Saat Kondisi Pasut Perekaman Citra (kiri), berdasarkan LLWL (kanan)

Adapun hasil pemodelan batimetri ini menghasilkan nilai negatif dibawah dari 0 dan maksimum nilai kedalaman yang dihasilkan yaitu $17 \mathrm{~m}$. Namun terdapat beberapa nilai kedalaman dibawah nilai 0 sampai dengan -4. Sehingga pada peta batimetri nilai kedalaman di bawah 0 dieliminasi karena merupakan nilai kedalaman dengan tingkat kesalahan tinggi. Hal ini dikuatkan oleh pernyataan Nurkhayati dan Khakhim (2013), bahwa nilai kedalaman di bawah nol dihilangkan karena merupakan nilai dengan bias yang cukup tinggi 


\section{KESIMPULAN}

1. Band rasio terbaik dalam membuat peta batimetri berdasarkan citra satelit Worldview-2 di perairan Pulau Parang yaitu band biru / hijau dengan nilai $\mathrm{R}^{2}$ 0,6976 dan RMSE sebesar 4,00.

2. Kedalaman laut berdasarkan citra satelit Worldview-2 di perairan Pulau Parang menunjukkan kedalaman dari $0 \mathrm{~m}$ hingga $17 \mathrm{~m}$.

\section{DAFTAR PUSTAKA}

Digital Globe. 2009. Radiometric use of WorldView-2 imagery. Technical note. Prepared by : Todd Updike, Chris Comp.

Hedley, J. D., Harborne, A. R., dan Mumby, P. J. 2005. Simple and robust removal of sun glint for mapping shallow-water benthos. Int. J. of Remote Sensing. 26(10): 2107-2112.

Hochberg, E. J., S. Andrefouet dan M. R. Tyler. 2003. Sea Surface Correction of High Spatial Resolution Ikonos Images to Improve Bottom Mapping in NearShore Environments. IEEE Trans. Geoscience and Remote Sensing. 41(7):1724-1729.

Nurkhayati, R. dan N. Khakhim. 2013. Pemetaan Batimetri Perairan Dangkal Menggunakan Citra Quickbird di Perairan Taman Nasional Karimun Jawa, Kabupaten Jepara, Jawa Tengah. Jurnal Bumi Indonesia, Vol. 2, No 2.

Stumpf, R. P., K. Holderied and M. Sinclair. 2003. Determination of water depth with high-resolution satellite imagery over variable bottom types. Applied Optics, Vol. 28(8):547-556.

Subarno, T., V. P. Siregar dan S. B. Agus. 2015. Evaluasi Citra Worldview-2 untuk Pendugaan Kedalaman Perairan Dangkal Pulau Kelapa-Harapan Menggunakan Algoritma Rasio Band. Journal of Geomatics and Planning Vol 2, No 1, hlm. 30-37.

Wicaksono, P. dan W. Rahman. 2019. Aplikasi Citra WorldView-2 untuk Pemetaan Batimetri di Pulau Kemujan Taman Nasional Karimunjawa. Jurnal Penginderaan Jauh Indonesia, Volume 01, No 01.

Wicaksono, P. 2015. Perbandingan Akurasi Metode Band Tunggal dan Band Rasio untuk Pemetaan Batimetri Pada Laut Dangkal Optis. Simposium Nasional Sains Geoinformasi IV. 